\title{
単結晶およびアモルファスシリコンの陽極酸化における発光現象
}

\author{
南 條 淳 二*, 仲 谷康, Sveinn'OLAFSSON ${ }^{\dagger}$, 野 村 滋
}

Luminescence Mechanism During Anodic Oxidation of Single Crystal

Silicon and Hydrogenated Amorphous Silicon

Junji NAN. $O^{*}$, Yasushi NAKATAY, Sveinn'OlarssoN ${ }^{\dagger}$ and Shigeru NOMURA

Received June 9, 1986 ; Accepted August 6, 1986

1.はじめに

水素化成アモルファスシリコン $(\mathrm{a}-\mathrm{Si}: \mathrm{H})$ は、大

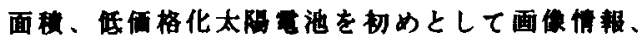
能助アパイス等方面の分野にわたって急速に使 用きれだし、数声くの鿬究、開発がなされている 現状である(1ー4)。

しかし、日-Si:H の表面化化技街は、a-Si:Hそ

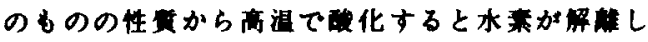
てしまい、氛気的な性兴加劣化することから、単 結聂シリコンで有奻な高沮破化プセスを用いる ことができない，a-Si:H 册材とのものを既化する

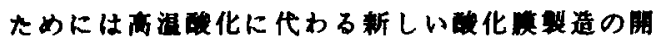

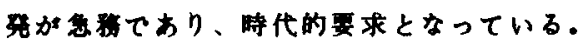

著者らは、これまで室沮に筑て可能な堂気化学

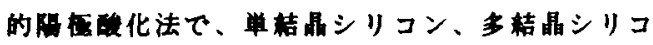
ン及びa-Si:H に䂾化莫を㔙成する研究を行なって きており、この方法を用いて、最近、的䂗に匹

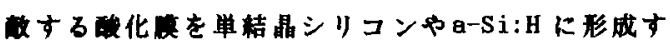
る直に成功している(5-8)。しがしがら、これら

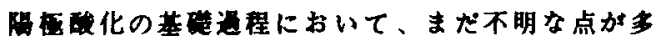

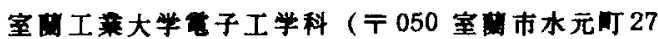

-1) Department of Electronic Engineering, Muroran Institute of Technology (27-1, Mizumoto-cho, Muroran 050)

+SIENCE INSTITUTE OF ICELAND（DUNHAGA 16, RE YKJAVIK, ICELAND)

Key Words: Anodic oxidation of $\mathrm{C}-\mathrm{Si}$ and a-Si:H, Luminescence
く存在しており、その一つに Schmidt やWaring の

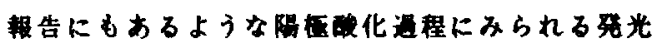

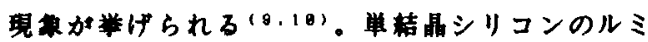
ネッセンスに閂してSchmidt らは、手子が高速で

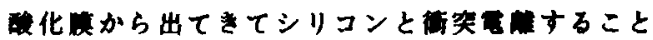
と閶保がると轱告している。また、Waring らは

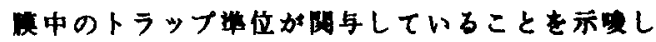

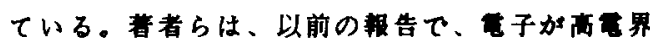

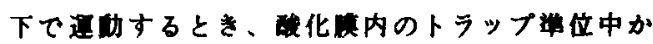

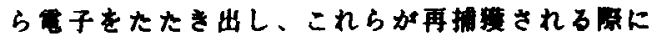

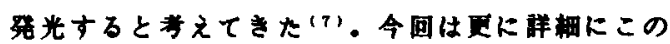

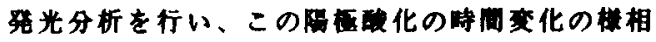

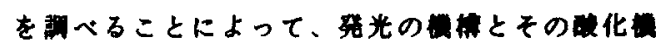

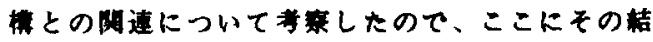
果を㫰告する。

\section{2. 英法方法}

使用した武科は、单结晶シリコンと a-Si:H 颠て おる。単耤奛シリコンは(111)面のN型で、比抵抗 は $10 \Omega-\mathrm{cm}$ である。これを样徍 $0.3 \mu \mathrm{m}$ のアルミナ

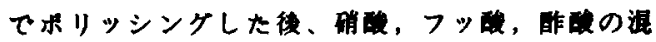

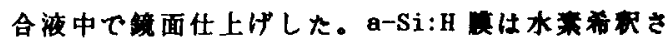
れたモノシランガスを济速50 SCCMで反応炉に浑 し、13.56MHz の高周波故的分解法で形成させた。

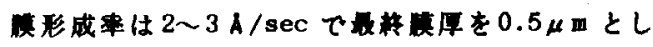
た。 a-Si:Hは不籹がトーピングきれておらず、

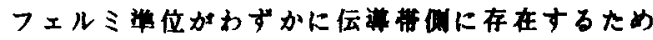
弱N型である。

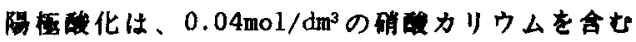


每水エチレングリコールを電解液に用い、雪湍密

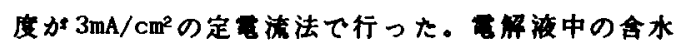
量はカールフィッシャー涌定の耛果 0.05 \%であっ

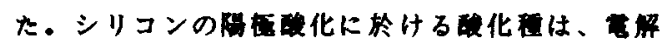
液中に初から入り込んでいる部量の水または、 解反分によって数しく生じた水加者えられてい

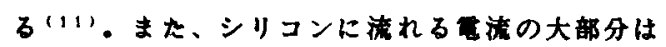

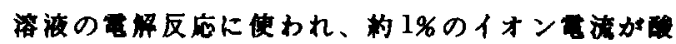

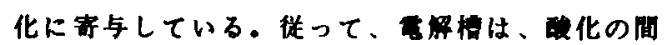
空気中から水がらないようにしてある。Fig.1

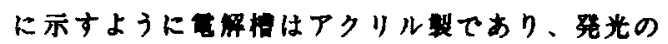
分光分析を行うために、武料と対向した解相の 整に石英板ガラスをセットしてある。石英板ガラ スの光の通波長篹圈は220〜2000nmであり、光 は一漛な强度で造通される。

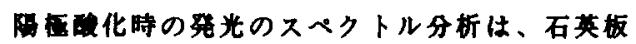
ガラスを通してモノクロメーターで行い、その强

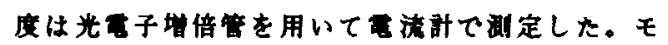
ノクロメータの走查速度は90nm/minで、光承子剒

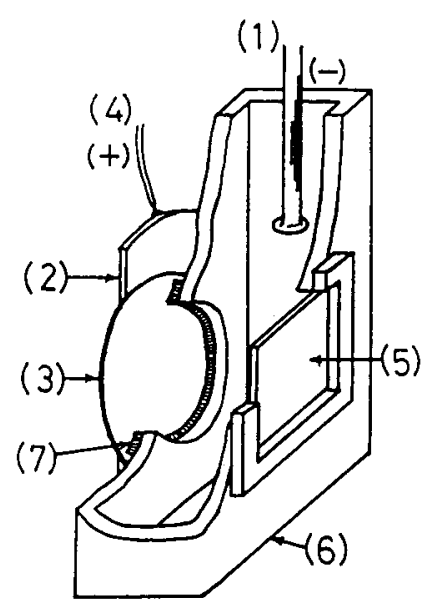

Fig. I Anodization cell

1. Platinum electrode 2. Aluminum electrode 3. Si wafer 4. Copper wire

5. Qualtz glass 6. Acrylic container

7. Rubber packing.
借管の印加雪圧は690Vである。汹定される発光强

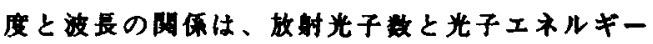

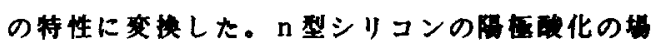

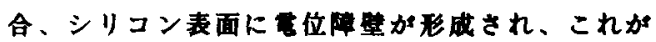

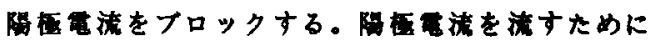

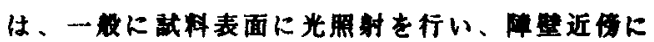
少数キャリアである正孔を生成しなけれはならな w.

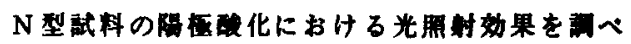
る目的で $10000 \mathrm{~lx}$.のパルス状の白色光を10sec 间 隔で武料表面に照的すると、ある一定の作化時间

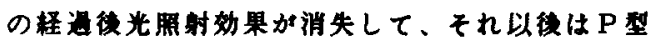

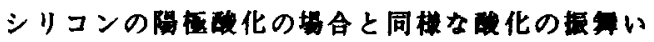

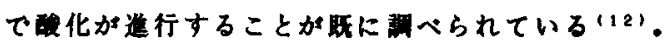

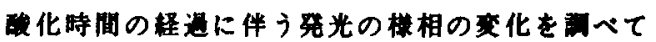

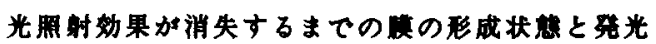

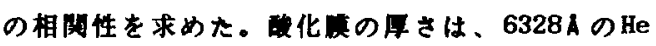
一Neガスレーザー光を光渢とするエリブソメトリー 法で澎定した。

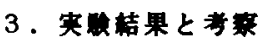

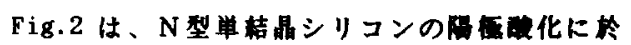

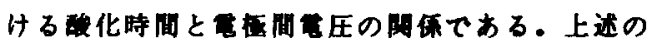

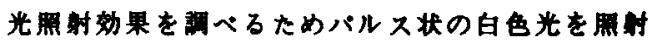

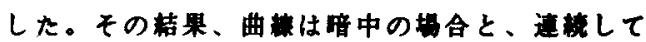

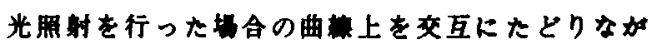

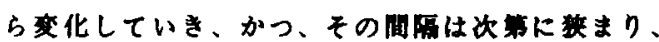
やがて一本の曲躃となって破化時间と其に上昇し、

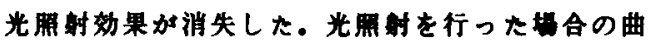

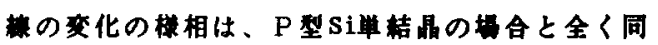
機であるい21。この原因は、徏述のルミネッセン スと大きな网かりがあるものと者えられ、そこて 合わせて考察する。a-Si:Hの场合にも全く同機な 振舞いが見られるが、光周射奻果が消海するまで の時間加単桔界の域合より長い。これは、a-Si:H

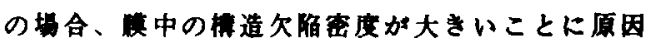
しているい'。

Fig. 3 は、単桔昆及び a-Si:H 境中に然ける

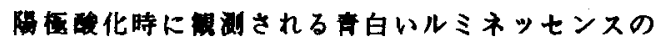




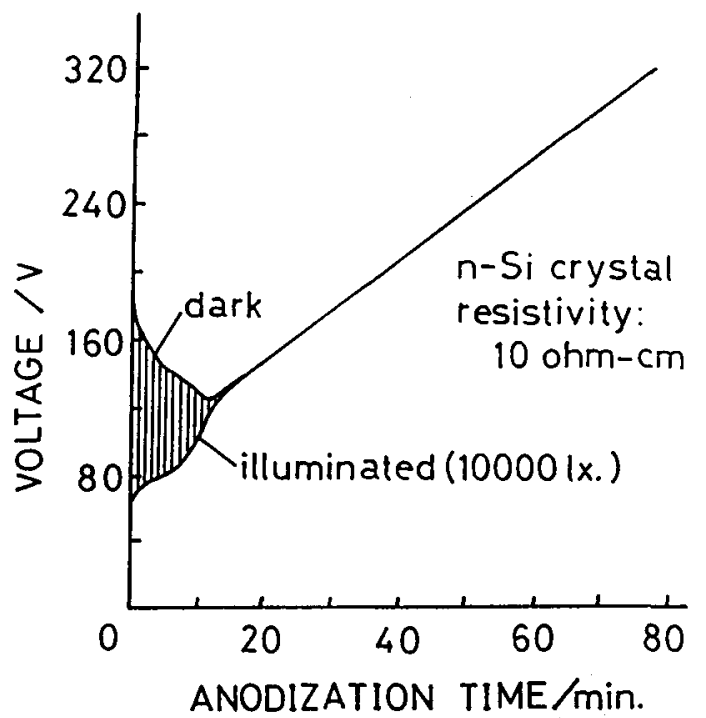

Fig.2 The voltage-time curves for a constant current anodization mode.

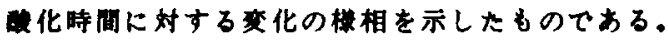
Fig.3-aは単桔晶シリコンの堨合のものである。 ルミネッセンスは、化の初期には、陚科端部に 部分的に現れ、眼化時间の释通と共に武科の中心 部へ向かって二次元的に移胹していき、やがて、 全面で発光が起こるようになる。

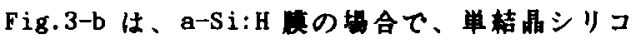
ンの场合と同桭に酸化の初期では部分発光から始 まる。しかし、その部分発光は随所で起こってお ク、かつ、その発光の二次元的広がりが整然と起 こっていない。その上に、光照射効果が消失する

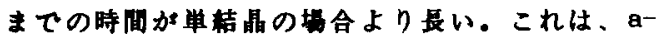

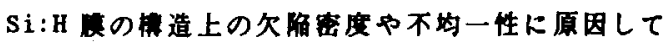
いるものと考える。

この部分発光から全面発光へと移行した時点と、 光周期効果が消失する時点は一致する。

两者とも全面発光の强度は酸化時间と共に增大 していく．発光の原因て、切期のこの部分発光は、 シリコン表面にかかる空そ展によって雪子が禹エ ネルギーを得て、硫化期とシリコン界面のシリコ ン表面の原子に得突する。この祭に起こる斯突。
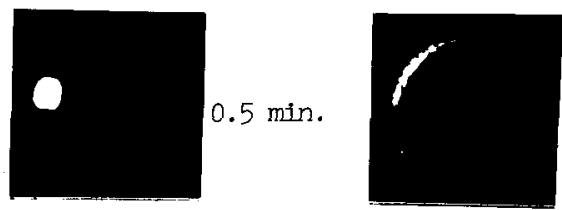

$3 \mathrm{~min}$.
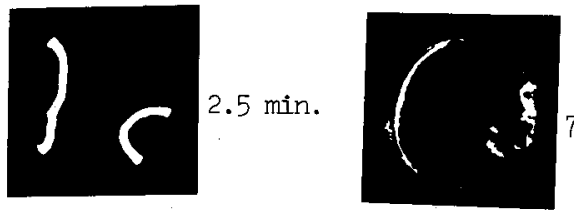

7 min.
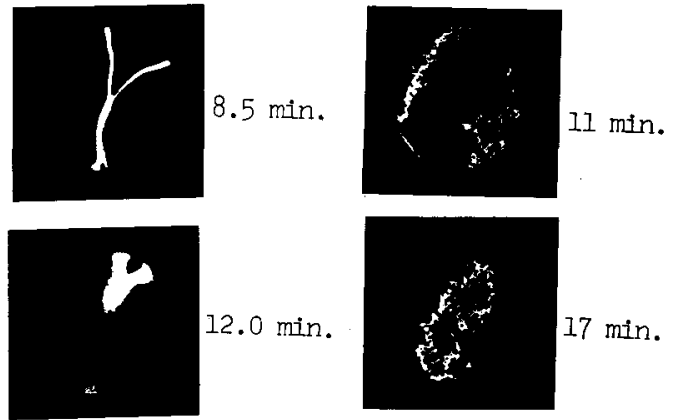

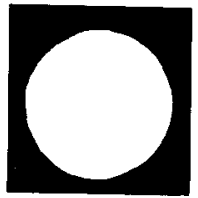

(a)

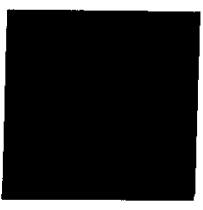

(
Fig.3 Growth of luminescence during anodization. (a) c-silicon and (b) a-Si:H.

部棈によると考えられるが、発光が全面で起こ

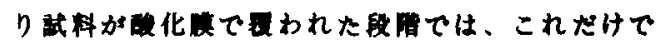
锐明できない新たな椣によるものが付加された と考えられ、それが $\mathrm{Si} / \mathrm{SiO}_{2}$ 界面近伐及ひ化化に あることが予意される。

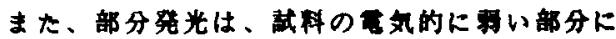

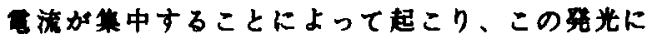
より生成した正孔が酸化反度に与し、その部分 では、化兴が尉成されているものと考える。因 みに、部分热光が起こっている途中て蛅化を中止

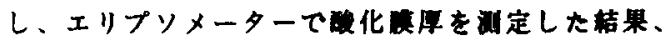

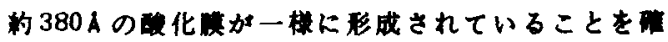


琶している(12)。

部分発光によって化傎が形成されると、䂾化

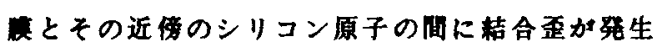

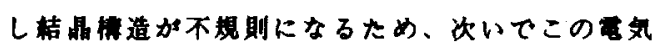
的に野い部分に震流の集中か移行する。これが部 分発光の二次元的広がりの原因となるものと考之 る.Fig.2で示した、暗中での定電流によるたル 压の娍少は、上述の楼な昰気的に不安定な部分 の広がりが起因しているものと巻える。

以上の䊅果から、これら二つのN型武料の场合、

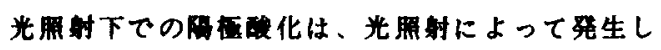

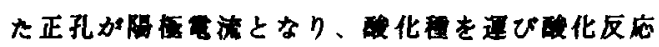

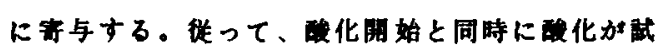

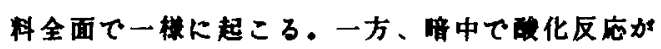

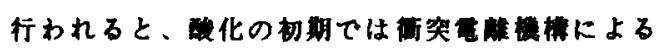

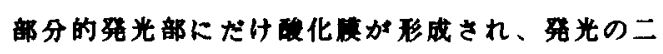

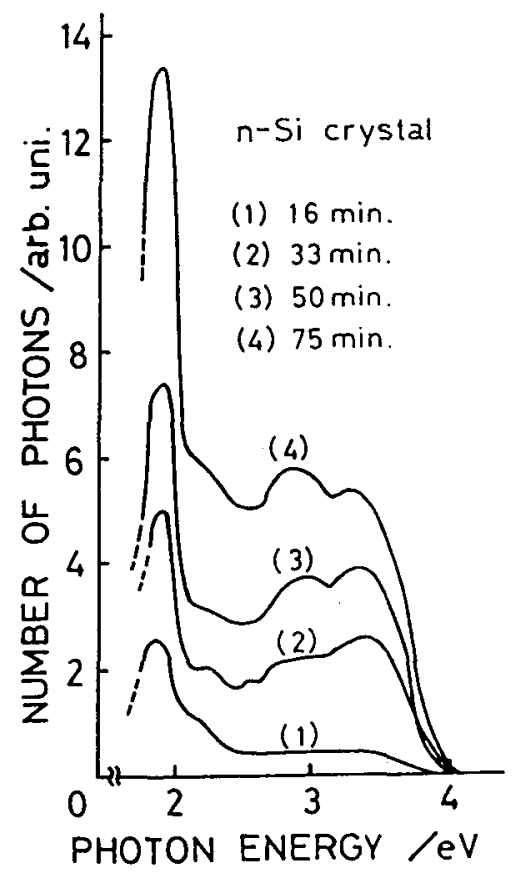

Fig. 4 Spectral distribution of the Iuminescence associated with the anodic oxidation of single crystal Si ( n-type).

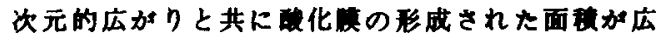
がる。全面発光に至って光照射奻果が失われた时 点で、試料全面から生ずるルミネッセンスによる

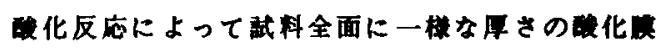
形成か開始されるものと考える。

Fig.4，Fig.5は、それそれ、単結旺シリコンと

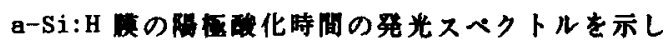
ている。两者とも呁 $1.7 \mathrm{eV} \sim 4.0 \mathrm{eV}$ の広いエネルキ 一筑困にわたってスヘクトル特性が得られた。こ の籍围内て、1.9eV, $2.9 \mathrm{eV}, 3.3 \mathrm{eV}$ 付近に特變的 なビークを有している。同図で、これらの放期光 子数は䂾化時と共に堷加しているが、特に $\mathrm{eV}$ 付近のピークは、部分発光の時点から陪だって 大きな值を示している。a-Si:Hの场合、3.3eV 付 近のピークが単結晶の堵合より明碃に現れていな い。また注意すへきことは、 $2.9 \mathrm{eV}$ と $3.3 \mathrm{eV} の$ 発 光は、光盟射效果加消失して全面䈳光に和行して

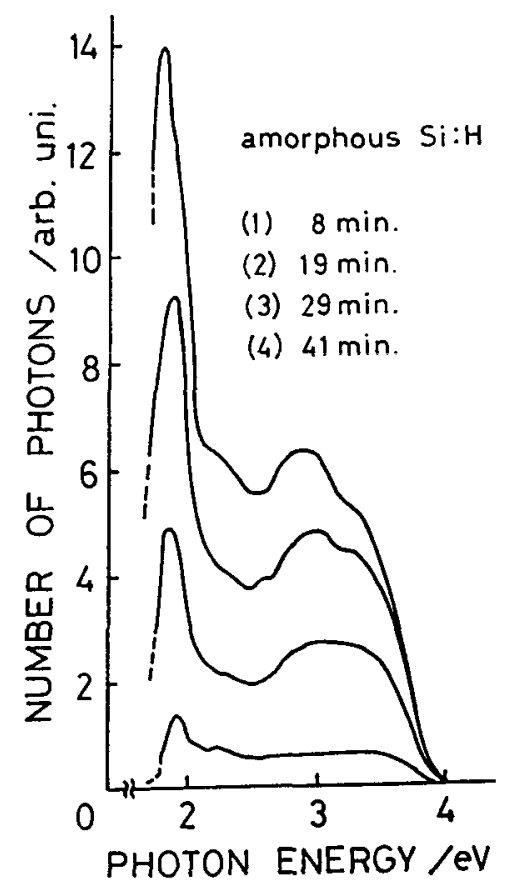

Fig.5 Spectral distribution of the luminescence during anodic oxidation of a-Si:H ( undoped). 


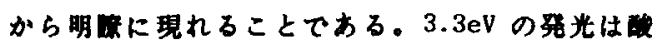

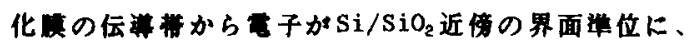

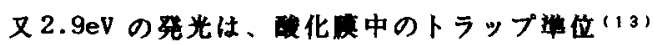
に落ちる咸に生ずると宩えている。これらのピー クは、ある一定の化時间になると急和の㑯向を 示す。特に、3.3eV 付近のピークにそれが著しい。 これは、化度の增加に伴い $\mathrm{Si} / \mathrm{SiO}_{2}$ 界面算位密 度や店中のトラップ密度の和化が起こったこと によるるのと孝える。

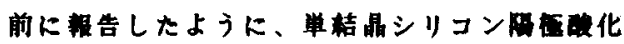
の场合、水来中でアニーリングを龍すと界面篗位 密度が娍少する(日)。本研究でも一度アニーリンク

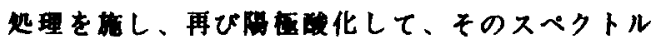
特性を訓べた。

Fig.6がその結果である。3.3eVのビークには、 化䦦始直掼汪とんと消失している。これから、 3.3eVのビークは、界面蓝位か閶与していること が判明した。2.9eV 付近の発光は、2.7eV と坻工

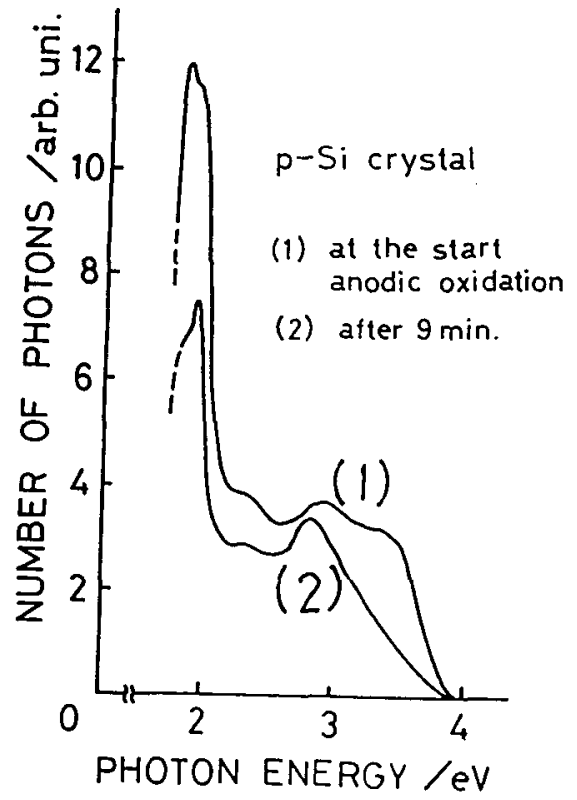

Fig.6 Spectral distribution of the Iuminescence associated with anodization of single crystal Si annealed in $\mathrm{H}_{2}$ gas after anodization.
ネルギー湖へ程到しているか、この付近の発光は、

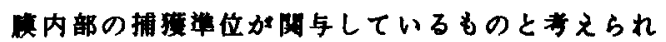
る。しかし、今のところ明碓な累银はなされてい 小。。

Fig. 7 は、単楛奛シリコンの合のこれら三ォ 所のビークの光子ェネルギーに於ける放财光子数 と破化時间の成係を示したものである。ただし、

Fig.3 とFig.4で得た测定䊅果より放期光子效 が大きいのは、使用した武科の面积が大きいこと による。前に述へたように、2.9eVと $3.3 \mathrm{eV}$ 付近 の故射光子数は、光照的奻果が消失し、全面発光 に移行した時点からある一定の時网の間直億的な 增加を示している。

次に、1.9eV 付近の放射光子数は、他のものと

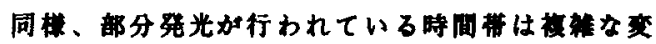
化を示しているか、その数は地のものよりも大き い、また、全面発光に移行すると、眼化时间と共 に指数阙的に增加している。

これら各々のピークの碳化時问による变化に奶

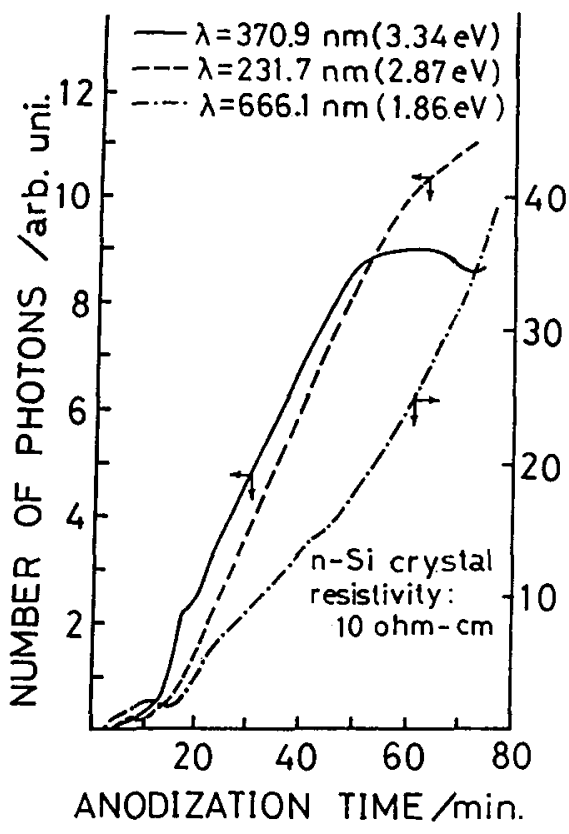

Fig.7 The change of emission intensity of the Iuminescence during anodization. 


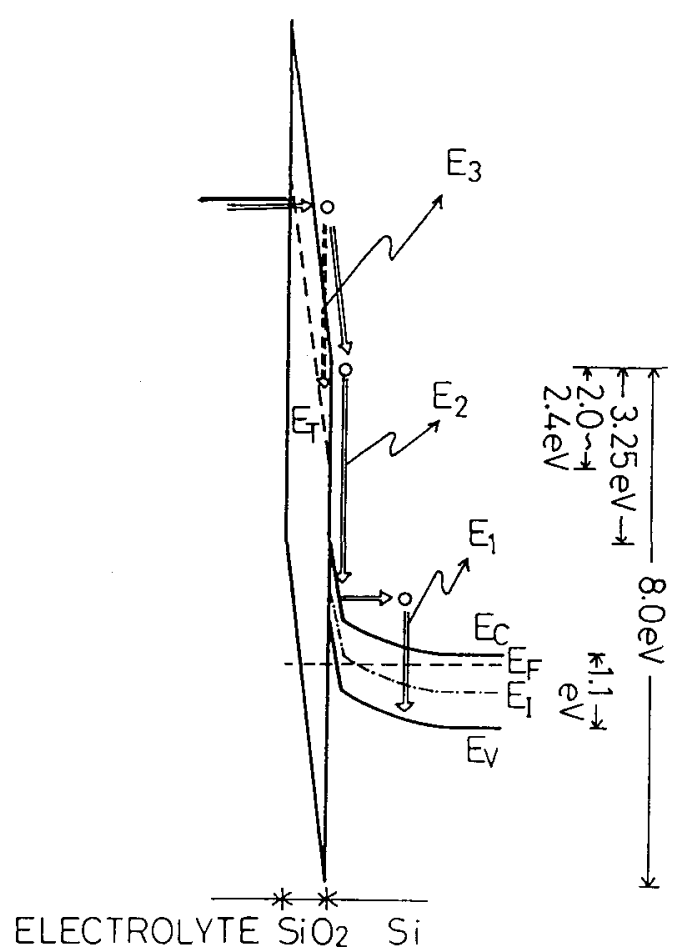

Fig.8 Energy band diagram of luminescence mechanisms during anodic oxidation of csilicon and amorphous silicon.

する蜼讨をFig.8 のエネルギーバンドモデルで行 ってみた。 $1.9 \mathrm{eV}$ 付近のエネルギー故出は。商 界によって事子が加速され、シリコン原子と解突

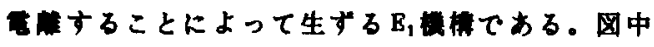
$\mathrm{E}_{2}$ の档による3.3eV 付近のエネルギー故出は、

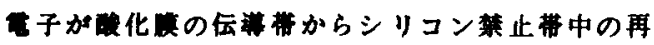

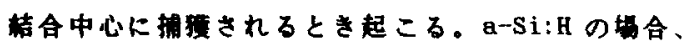
この光子ェネルギーでのピークが単結晶シリコン

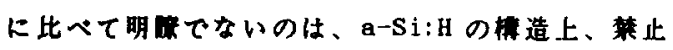

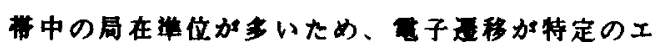
ホルギーに集中しないことによると考える。2.9 eV 付近のエネルギーは、化傎中のトラップ位

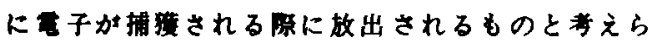

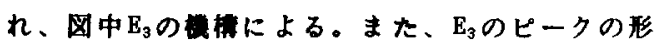

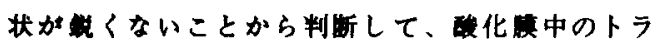

ップから、シリコン禁止弗中への再结合中心に落

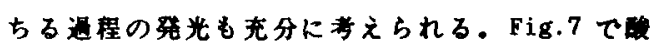

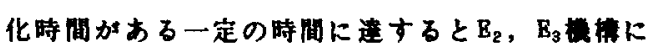

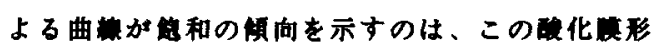
成策件で、asーgrown 就として、基、界面特性が 安定化に向かったことに原因すると侾えられる。 化の切期の部分発光から全面発光へ移行した段 階で光照射奻果が失われるのは、この

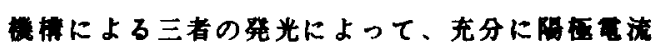
が渗れ化程が供粭されるからである。

以上、バンド図によって無光榙槽を跘明してみ

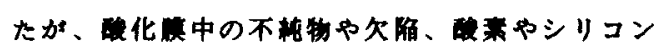
イオンの化化中の移助についても青感す西必要 があると思われる。

\section{䊅的}

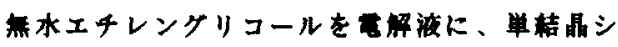

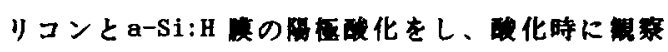
される発光のスへクトル分析をし、その器光目槽

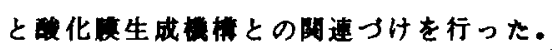

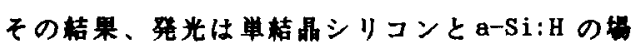
合とも $1.7 \mathrm{eV} \sim 4.0 \mathrm{eV}$ の広籍团によって起こってお $\eta 、 そ の$ 中で、1.9ev, $2.9 \mathrm{eV}, 3.3 \mathrm{eV}$ 付近に特篎 的なピークを有することが判明した。1.9eVのピ

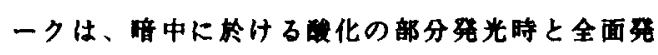

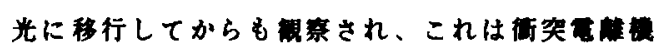

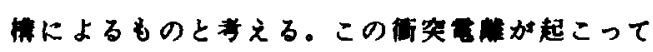
いる部分では局所的に化反应が焦行している。

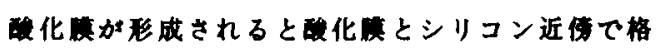
子の乱れが生し、発光はその位再に程行する。結

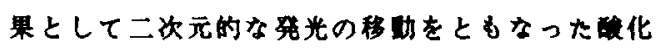
反応が起こク、やがて、武料全面で化反分が起 こク、同時に発光も全面で起こるようにるる。全 面発光に伴って新しく生した $2.9 \mathrm{eV}$ 付近の発光は 化傎のトラップ位へ、3.3eVの器光は、眼化

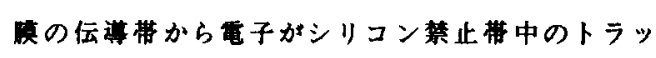

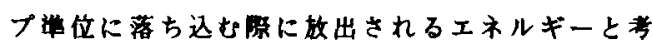
えられる。

N型シリコン及びノンドープa-Si：H 㬺の檑酸 
化に於て、光捅射效果が消失するのは、 $E_{1} ， E_{2}$ ， $\mathrm{B}_{3}$ モテルの発光到によって、正孔が充分に生成

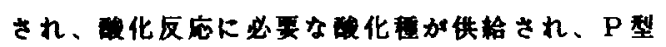

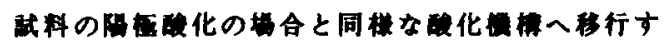
るものと萧える。

$$
\text { 文献 }
$$

(1) D.E.Carlson, IEEE Trans. Blectron Devices, $\mathrm{ED}-24,4$ (1977)

(2) J.I.B.Wilson and P.Robinson, SolidState Electronics, 21, 489(1978)

(3) P.G. Le Comber, W.B.Spear and Ghaith, Electronics Letters, $\underline{15}, 6(1976)$

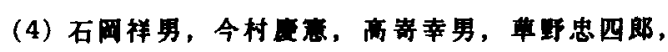
平井忠明，佰時三郎，实子道信学会技衡研究 银告， 82, 154; ED85-72 (1982)

(5) H. YAMAMOTO, S. ARIMOYO, H. HASEgAWA, H.OHNO and J.NANJO, Electronics Letters
6 th, Jan. , 19, 1(1983)

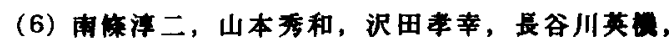
電匃化学, 吕, 5(1983)

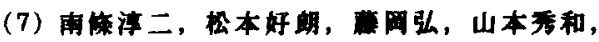

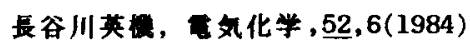

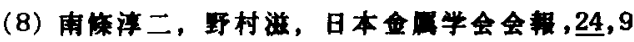
(1985)

(9) P.F.Schmidt and W.Michel, J. Electrochem. Soc., 104,4(1957)

(10) W.Waring and E.Benjamini, J. Electrochem. Soc., $111,11(1964)$

(11) E.F.Duffek, E.A.Benjamini and C.Mylroie, Electrochem. Technol., 3,75 (1965)

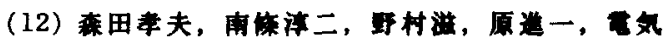
化羊, 吕, 11(1977)

(13) S.M.Sze, "Physics of Semiconductor Devices" John Wiley and Sons, Inc. (1969)

Abstract

The luminescence spectra during the anodic oxidation of single crystal and hydrogenated aworphous silicon in non-aqueous ethylene glycol solutions have been analyzed to correlate between the oxidation mechanism and the luminescence phenomenon. Both the spectrum for single crystal and that for amorphous silicon show similair emission bands over the range of $1.7 \sim 4.0 \mathrm{eV}$ with strong enission peaks at $1.9,2.9$ and $3.3 \mathrm{eV}$.

The emission peak at $1.9 \mathrm{eV}$ may be due to collision ionization of silicon at the surface of $\mathrm{SiO} / \mathrm{Si}$ by electron coming out the oxide with a high speed. This collision ionization occurs in the localized area at an early stage of oxidation. The luminescence is observed first in spots at the periphery of the specimen with which the solution contacts, then it diffuses and expands to the center with the spots collapsing and finally spreads over the entire surface of the specimen. The peaks at $2.9 \mathrm{eV}$ and $3.3 \mathrm{eV}$ appear after the luminescence spread over the whole surface. The eaission at $2.9 \mathrm{eV}$ is due to the electron capture by the trap centers in the oxide and the peak at $3.3 \mathrm{eV}$ is attributable to the electron trapping by the interface states at the $\mathrm{Si} / \mathrm{SiO}_{2}$ interface.

As the oxide grows, the lattice distortion occurs at the boundary between the surface with and without the oxide. The luminescence moves to the boundary with diffusing and expanding.

It is concluded that the luminescence produces the electron-hole pairs and the oxidation reaction proceeds with the contribution of the produced hole. 